\author{
${ }^{1}$ Department of Animal Science, Faculty of Agriculture, Ege University, Izmir-Turkey \\ ${ }^{2}$ Ege Agricultural Research Institute, Izmir-Turkey

\section{Growth curve analysis for body weight and dry matter intake in Friesian, Limousin $x$ Friesian and Piemontese $x$ Friesian cattle}

\begin{abstract}
In this study, body weight and dry matter intake from birth to 460 days of age of Friesian (F), Limousin $x$ Friesian (LixF) and Piemontese x Limousin (PixF) cattle fed individually under intensive feeding system were analyzed. Growth curve parameters of body weight and dry matter intake were investigated by using Gompertz model. No significant differences between genotypes were found in growth curve parameters for dry matter intake while there was significant genotype effect on integration constant, absolute weight gain at birth, degree of maturity at birth and absolute body weight gain from birth to 6 months of age for body weight. Mean values of growth parameters for body weight in F, LixF and PixF were: mature weight 744, 801 and 743 kg; integration constant 2.97, 3.02 and 2.81; maturity rate per day 0.0045, 0.0042 and 0.0047; age at inflection point 245, 270 and 227 days; weight of inflection point 274, 295 and 273, respectively. Body weight at birth for F, LixF and PixF were 38.6, 44.4 and 49.1. Absolute body weight gain from birth to 6 months of age for F, LixF and PixF were 24.8, 21.9 and 25.3. PixF exhibited higher maturity rate and reaching mature weights younger than $F$ and LixF. Mature weight for body weight had positive phenotypic correlations with mature weight parameter for dry matter intake whereas there was a negative phenotypic correlation between mature weight for body weight and maturity rate for dry matter intake in all genotypes. The result shows that increasing intake is a result of body weight increased. On the other hand feed intake rate decreased as body weight increased. Considering the development period, from birth to 6 months of age, there was significant difference between genotypes for absolute body weigh gain and absolute dry matter intake whereas these parameters did not differ significantly between 6 and 16 months.
\end{abstract}

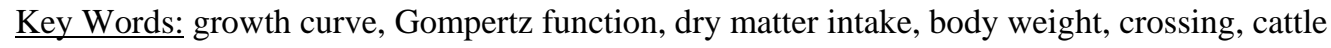

\title{
Zusammenfassung
}

Titel der Arbeit: Wachstumskurvenanalyse für Körpergewicht und Trockenfutteraufnahme bei Friesian, Limousin x Friesian und Piemontese x Friesian Rindern

Analysiert wurden die Körpergewichte und Trockenmasseaufnahmen von 21 Mastbullen von Geburt bis zur Schlachtung (460 Tage) der Rassen bzw. Kreuzungspopulationen Friesian (F), Limousin x Friesian (LixF) und Piemontese x Friesian (PixF). Die Tiere wurden einzeln gehalten und intensiv gefüttert. Mittels der Gompertzfunktion wurden Wachstumskurvenparameter von Körpergewicht und Trockenmasseaufnahme untersucht. Zwischen den Genotypen ergaben sich keine signifikanten Unterschiede bei den Wachstumskurvenparametern für die Trockenmasseaufnahme, wobei signifikante Unterschiede für die Integrationskonstante, das Geburtsgewicht, den Reifegrad bei Geburt sowie die Lebendmassezunahme bis zum Alter von sechs Monaten festgestellt wurden. Die Mittelwerte der Wachstumsparameter bei den Genotypen F, LixF und PixF betrugen für das Reifegewicht 744; 801 und 743 kg, die Integrationskonstante 2,79; 3,02 und 2,81, die Reiferate pro Tag 0,0045; 0,0042 und 0,0047, das Alter an den Flexionspunkten 274; 295 und 273 Tage und das Lebendgewicht bei Geburt 38,6; 44,4 und 49,1 kg. Die Lebendgewichtszunahme von Geburt bis zum Alter von sechs Monaten betrug 24,8; 21,9 bzw.25,3 kg. Die PixF Bullen hatten eine höhere Reiferate und erreichten das Reifegewicht früher als die F und LixF Tiere. Positive phänotypische Korrelationskoeffizienten wurden bei allen Genotypen für die Beziehung Körpergewicht zu Trockenfütteraufnahme beobachtet während negative Beziehungen zwischen Reifegewicht für Körpergewicht und Reiferate pro Tag für Trockenfütteraufnahme geschätzt wurden. Dieses Ergebnis zeigt, dass die zunehmende Trockenfutteraufnahme ein Resultat zunehmenden Körpergewichtes ist. Darüber hinaus nahm die Futteraufnahmerate ab, während das Körpergewicht zunahm. Berücksichtigt man die Entwicklungsperiode Geburt bis sechs Monate ergaben sich signifikante Unterschiede zwischen den Genotypen sowohl für die Lebendgewichtzunahme als auch die Trockenmasseaufnahme. Für den Altersabschnitt 6-16 Monate konnten keine signifikanten Differenzen nachgewiesen werden. 
Schlüsselwörter: Wachstumskurve, Gompertzfunktion, Trockenmasseaufnahme, Körpergewicht, Kreuzung, Rinder

\section{Introduction}

Piemontese and Limousin breeds had been evaluated for crossing on Friesian dairy cows in several European countries (MCGUIRK et al., 1998; JACUBEC et al., 2003). In majority of these studies, Piemontese progeny out of Friesian cows had a higher growth rate than Limousin (HRÛSKA 1993; GRUNDY et al., 2000). This growth superiority over Limousin was not confirmed by recent findings (FREELICH et al., 1998; HOVING-BOLINK et al., 1999). However, there was no published information on the growth rate of progeny from these breeds in Turkish intensive feeding system. For this reason, a research has been performed to investigate the feedlot performance and carcass and meat quality of Piemontese $\mathrm{x}$ Friesian and Limousin $\mathrm{x}$ Friesian young bulls versus Friesian young bulls under intensive beef production system in Turkey (ALCICEK et al., 2003; GUNGOR et al., 2003). But, growth rates of F, LixF and PixF genotypes were not evaluated in the mentioned studies.

In Turkey, meat producers prefer rapid maturing beef breeds for crossing on dairy cows in beef production. As well known, rapid growth until slaughter weight is an important goal for increased meat production (CARRIJO and DUARTE, 1999; CHAMBAZ et al., 2001). However, a genotype with high growth rate may not necessarily provide an improvement in biological efficiency (lean tissue produced / food consumed) over a slower growing animal with the same mature size, as it may have higher feed intake at maturity than the slower growing animal (ARCHER et al., 1998). Furthermore, some authors indicate that selection of cattle for higher maturity rates may lead to lighter weights at maturity (NELSEN et al., 1982; BULLOCK et al., 1993). The individual growth curve parameters, both basic and derived, are suitable phenotypic variables for the assessment of growth pattern and maturity (KRATOCHVILOVÁ et al., 2002; GOYACHE, et al., 2003). Several nonlinear growth models were available for mathematical description of growth curve such as logistic, Gompertz, Brody, Von Bertalanffy and Richards (AKBAS, 1995; MATTHES et al., 1996). However, most common function in use for different species is Gompertz (MEYER, 1995; NEŠETŘILOVÁ et al., 1999). Growth parameters, such as mature weight and general maturity rate, estimated from weights taken periodically during the life of the animal, can be used to evaluate development of animals (LEHMANN, 1979). However, in beef production, dry matter intake (DMI) of an animal is also as important as body weight gain. DMI is determined to meet requirements for maintenance and growth (NRC, 1987). Likewise, the changes in the shape of the growth curve can be as a result of pattern of feed intake (PAPSTEIN et al., 1995). It is easy to comment on growth of animal when feed intake is considered. Feed is also major cost in beef production and thus there is a need to improve the efficiency of its utilisation (ARTHUR et al., 1998). In this study, rather than review previous experimental results, the results of incorporating estimated growth curves parameters for body weight and dry matter intake were evaluated to present input (feed) and output (body weight gain) relationships. A number of recent reviews have generally concluded that a change in mature body weight has a little effect on the biological efficiency of a meat producing enterprise, because of the associated changes in other feeding and growth parameters (THOMPSON and BARLOW, 1986; ARTHUR et al., 
1998; GOLZE, 2001). Consequently, the purposes of the present study were to estimate the growth curve parameters for body weight and dry matter intake of F, LixF and PixF males which individually reared under intensive feeding system and to compare growth rates of these genotypes using body weight and dry matter intake measurements.

\section{Material and Methods}

The oestrous of Friesian cows, of the same age, was synchronised and these cows were artificially inseminated randomly with semen obtained from one Friesian (F), Piemontese (Pi) and Limousin (Li) bull. Calving occurred within 30 days in the Ege Agricultural Research Institute in Izmir. A total of 21 male calves consisting of 7 F, 7 PixF and 7 LixF were used in the present study. Animals were individually penned and weaned at the age of 60 days. Then, they were reared from 60 to 180 days of age under uniform management. After that they were moved to individual tied stalls for an intensive fattening period from 180 to 460 days. All animals were fed individually with a fixed amount of wheat straw (92 \% DM, 6 \% CP, 1.2 \% EE, 31 \% CF and 1512 $\mathrm{kcal} \mathrm{ME} / \mathrm{kg}, 1 \mathrm{~kg} /$ day) and increasing amounts of concentrate from 5 to $9 \mathrm{~kg} / \mathrm{day}$ (91 \% DM, $15 \% \mathrm{CP}, 2$ \% EE, 5 \% CF and $2655 \mathrm{kcal} \mathrm{ME} / \mathrm{kg}$ ) to meet the increasing energy and protein requirements according to NRC (1987). Body weight, body weight gain and feed intake of F, PixF and LixF bulls were given in Table 1.

Table 1

Body weight, body weight gain and feed intake of F, PixF and LixF bulls (Körpergewicht, tägliche Zunahme und Futteraufnahme bei F, PixF und LixF Rindern)

\begin{tabular}{lcccc}
\hline \multirow{2}{*}{ Parameter } & \multicolumn{3}{c}{ Breed } & \multirow{2}{*}{ SEM } \\
\cline { 2 - 4 } & $\mathrm{F}$ & PixF & LixF & 4.32 \\
Initial weight, kg & $204 \mathrm{~b}$ & $220 \mathrm{a}$ & $195 \mathrm{~b}$ & 12.35 \\
Slaughter weight, kg & 501 & 519 & 488 & 49.35 \\
Daily live weight gain, g & 1059 & 1066 & 1044 & 0.23 \\
Daily concentrate intake, kg & 7.46 & 7.37 & 7.19 & 0.21 \\
Dry matter intake, kg & 6.77 & 6.69 & 6.53 & 0.03 \\
Crude protein intake, kg & 1.11 & 1.10 & 1.07 &
\end{tabular}

Analysis of concentrate and straw was made according to the German system (NAUMANN and BASSLER, 1993). During the trial, the animals were weighed 17 times for every 28 days from the birth until 460 days of age (prior to slaughter). The quantities of feed offered were recorded daily throughout the experiment.

The following Gompertz function that is suitable for shape of growth curve in cattle (MEYER, 1995; KRATOCHVILOVÁ et al., 2002) was chosen to estimate individual curve parameters:

$y_{t}=A e^{-b e^{-k t}}$

where $\mathrm{Y}_{\mathrm{t}}=$ is body weight $(\mathrm{BW})$ at time $\mathrm{t}$ (age of animal since birth), $\mathrm{A}$ is asymptotic $\mathrm{BW}$ (final or mature $\mathrm{BW}$ ), $\mathrm{B}$ is the integration constant which is time scale parameter and related to birth weight $\left(\mathrm{W}_{0}\right)$ as $\mathrm{B}=\ln \left(\mathrm{A} / \mathrm{W}_{0}\right)$. The parameter $\mathrm{K}$ is the relative growth rate. To understand the shape of the growth curve, age $\left(\mathrm{t}^{*}\right)$, weight $\left(\mathrm{W}^{*}\right)$, maximum weight gain $\left(\mathrm{K}^{*}\right)$ at time of inflection point where growth rate is maximum were calculated as $t^{*}=\ln (B) / K ; W^{*}=A / e$ and $k^{*}=A^{*} K / e$, respectively. In addition to that degree of maturity $\left(U_{t}\right)$, proportion of mature size attained at age $t\left(u_{t}=y_{t} / A\right)$ at birth, 6 and 16 months of age $\left(\mathrm{u}_{0}, \mathrm{u}_{6}\right.$ and $\left.\mathrm{u}_{16}\right)$ were considered. Other parameter was 
age of animal reached to $75 \%$ of mature weight $\left(\mathrm{t}_{0.75 \mathrm{~A}}\right)$. The differences in body weights in absolute weight gains from birth to 6 months of age and from 6 to 16 months of age $\left(\mathrm{BW}_{6}-\mathrm{BW}_{0} / 6 ; \mathrm{BW}_{16}-\mathrm{BW}_{6} / 10\right)$ were also calculated. Same growth curve parameters were estimated for dry matter intake (DMI) using the same model.

Following linear model was used to compare genotypes for the curve parameters of BW and DMI:

$\mathrm{y}_{\mathrm{ij}}=\mu+\mathrm{G}_{\mathrm{i}}+\mathrm{e}_{\mathrm{ij}}$

where $\mathrm{y}=$ growth curve parameters for $\mathrm{BW}$ or DMI,

$\mu=$ overall mean,

$\mathrm{G}_{\mathrm{i}}=$ fixed effect of the genotype, $\mathrm{i}=1$ to 3 ,

$\mathrm{E}_{\mathrm{ij}}=$ residual error distributed as $\mathrm{N}\left(0, \sigma^{2}\right)$.

Phenotypic correlation coefficients between growth curve parameters for BW and DMI were also estimated. Nonlinear model [1] to estimate growth curve parameters and the linear model [2] to identify genotype differences were fit using SPSS (1997).

\section{Results}

\section{Body weight growth curve parameters}

Observed and estimated growth curves for body weight were plotted in Figure 1A. To compare growth performances of genotypes, estimated growth curves of all genotypes for BW were given in Figure 2A. PixF was the earlier maturing genotype and the body weights of PixF in all ages were clearly higher than the other genotypes. Growth performance of LixF and $\mathrm{F}$ were similar especially at the beginning and at the end of growing period.

Means of the individual growth curve parameters for BW were given in Table 2 . Among parameters given in Table 1, only the parameters $\mathrm{B}, \mathrm{BW}_{0}, \mathrm{U}_{0}$ and $\mathrm{ABWG}_{0-6}$ were influenced by genotype $(\mathrm{P}<0.05)$. Obtained values for the parameter $\mathrm{B}$ were 2.97, 3.02 and 2.81 for F, LixF and PixF, respectively. Since parameter B is negatively related to birth weight, B was lower and BW at birth was higher for PixF compared to the other genotypes. In this study, LixF which had low growth rate $(\mathrm{K})$, matured late but exhibited heavier mature weight than $\mathrm{F}$ and PixF although the differences were insignificant. As shown in Figure 2A, PixF matured earlier than F and LixF.

Table 2

Estimated growth curve parameters for body weight (Geschätzte Wachstumskurvenparameter für das Körpergewicht)

\begin{tabular}{|c|c|c|c|c|c|c|c|}
\hline \multirow[b]{3}{*}{ Parameter } & \multicolumn{6}{|c|}{ Genotype } & \multirow{3}{*}{$\mathrm{P}$} \\
\hline & \multicolumn{2}{|l|}{$\mathrm{F}$} & \multicolumn{2}{|l|}{ LixF } & \multicolumn{2}{|l|}{ PixF } & \\
\hline & Mean & SE & Mean & SE & Mean & SE & \\
\hline $\mathrm{A}(\mathrm{kg})$ & 743.9 & 54.06 & 800.7 & 57.20 & 742.5 & 53.07 & 0.698 \\
\hline B & $2.97^{\mathrm{ab}}$ & .059 & $3.02^{\mathrm{a}}$ & .053 & $2.81^{\mathrm{b}}$ & .064 & 0.049 \\
\hline K (per day) & .0045 & .00025 & .0042 & .00023 & .0047 & .00025 & 0.398 \\
\hline $\mathrm{BW}_{0}(\mathrm{~kg})$ & $38.6^{c}$ & 1.48 & $44.4^{\mathrm{b}}$ & 1.86 & $49.1^{\mathrm{a}}$ & 0.59 & 0.000 \\
\hline $\mathrm{T}^{*}$ (day) & 245.2 & 18.97 & 269.6 & 18.44 & 226.6 & 15.22 & 0.251 \\
\hline $\mathrm{W}^{*}(\mathrm{~kg})$ & 273.7 & 19.89 & 294.6 & 21.04 & 273.2 & 19.52 & 0.698 \\
\hline $\mathrm{U}_{0}$ & $.053^{\mathrm{c}}$ & .0029 & $.057^{\mathrm{ab}}$ & .0046 & $.068^{\mathrm{a}}$ & .0045 & 0.046 \\
\hline $\mathrm{U}_{6}$ & .26 & .0202 & .23 & .0164 & .28 & .0196 & 0.177 \\
\hline $\mathrm{U}_{16}$ & .70 & .0392 & .63 & .0345 & .72 & .0316 & 0.208 \\
\hline $\mathrm{T}_{0.75 \mathrm{~A}}$ (day) & 524.9 & 35.68 & 572.1 & 35.10 & 499.1 & 29.2 & 0.317 \\
\hline K* (per day) & 1.22 & .029 & 1.21 & .024 & 1.24 & .033 & 0.664 \\
\hline $\mathrm{ABWG}_{0-6}(\mathrm{~kg})$ & $24.8^{\mathrm{a}}$ & .79 & $21.9^{b}$ & .30 & $25.3^{\mathrm{a}}$ & .45 & 0.001 \\
\hline $\mathrm{ABWG}_{6-16}(\mathrm{~kg})$ & 32.2 & .91 & 32.0 & .96 & 32.7 & 1.44 & 0.911 \\
\hline
\end{tabular}


PixF reach to the maximum growth rate (age at point of inflection) 19 days earlier than $\mathrm{F}$ and 43 days earlier than LixF and had similar weight at point of inflection with F. LixF was late matured and become the heaviest $(294.6 \mathrm{~kg})$ genotypes at point of inflection age. Degree of maturity at birth $\left(\mathrm{U}_{0}\right), 6\left(\mathrm{U}_{6}\right)$ and $16\left(\mathrm{U}_{16}\right)$ months of age and absolute growth rate $\left(\mathrm{K}^{*}\right)$ at the point of inflection were slightly higher in PixF. While PixF reach to $75 \%$ of the mature weight in 499 days, $\mathrm{F}$ and LixF reach the concerned weight 26 and 76 days later than PixF, respectively. ABWG until 6 months of age was quite different between genotypes whereas the differences for ABWG from 6 to 16 months were insignificant.

\section{Dry matter intake curve parameters}

Observed and estimated curves for dry matter intake (DMI) were plotted in Figure 1B. Estimated DMI curves of all genotypes for DMI were compared in Figure 2A. DMI values from 70 to 275 days of age were higher in PixF than the other genotypes. Although DMI of F was generally in between the other two genotypes, DMI of F became the highest after 275 days as seen in Figure 2B. DMI of LixF was lowest in all cases.

Means of the individual curve parameters for DMI were given in Table 3. Differences between genotypes for the curve parameters except $\mathrm{ADMI}_{0-6}$ for $\mathrm{DMI}$ were insignificant. Although there was no significant difference between genotypes in A for DMI, F was higher than crosses, that means mature age feed consumption was higher in F compare to other genotypes. This result is also shown in Figure 2B. However, K parameter for DMI was lower in F compared to crosses. Small K parameter for F resulted in high A value for DMI, oppositely high $\mathrm{K}$ parameter in crosses indicated slightly fast feed intake rate and smaller A for DMI. Besides, initial dry matter intake was higher for this genotype since the parameter B for DMI was found lower in F.

Table 3

Estimated growth curve parameters for dry matter intake (Geschätzte Wachstumskurvenparameter für die Trockenmasseaufnahme)

\begin{tabular}{|c|c|c|c|c|c|c|c|}
\hline \multirow[b]{3}{*}{ Parameter } & \multicolumn{6}{|c|}{ Genotype } & \multirow{3}{*}{$\mathrm{P}$} \\
\hline & \multicolumn{2}{|l|}{$\mathrm{F}$} & \multicolumn{2}{|l|}{ LixF } & \multicolumn{2}{|l|}{ PixF } & \\
\hline & Mean & SE & Mean & SE & Mean & SE & \\
\hline $\bar{A}(\mathrm{~kg})$ & 225.6 & 10.89 & 216.9 & 2.99 & 219.3 & 8.80 & 0.753 \\
\hline B & 5.5 & 0.59 & 6.4 & 0.86 & 6.8 & 0.96 & 0.546 \\
\hline K (per day) & 0.016 & 0.0016 & 0.019 & 0.0009 & 0.021 & 0.0023 & 0.326 \\
\hline $\mathrm{T}^{*}$ (day) & 98.1 & 4.20 & 99.4 & 1.93 & 92.1 & 4.73 & 0.375 \\
\hline $\mathrm{W}^{*}(\mathrm{~kg})$ & 82.9 & 4.00 & 79.8 & 1.09 & 80.7 & 3.24 & 0.753 \\
\hline $\mathrm{U}_{6}$ & 2.1 & 0.12 & 2.2 & 0.054 & 2.4 & 0.17 & 0.221 \\
\hline $\mathrm{U}_{16}$ & 11.6 & 0.27 & 11.8 & 0.051 & 12.2 & 0.25 & 0.260 \\
\hline $\mathrm{T}_{0.75 \mathrm{~A}}$ (day) & 169.2 & 8.17 & 162.7 & 2.24 & 164.5 & 6.60 & 0.753 \\
\hline $\mathrm{K}^{*}$ (per day) & 1.4 & 0.082 & 1.5 & 0.072 & 1.6 & 0.11 & 0.141 \\
\hline $\mathrm{ADMI}_{0-6}(\mathrm{~kg})$ & $79.1^{\mathrm{b}}$ & 1.25 & $78.1^{\mathrm{b}}$ & 2.30 & $87.4^{\mathrm{a}}$ & 3.24 & 0.027 \\
\hline $\operatorname{ADMI}_{6-16}(\mathrm{~kg})$ & 213.9 & 7.38 & 208.4 & 2.95 & 212.9 & 7.14 & 0.232 \\
\hline
\end{tabular}

Age at point of inflection ( $\mathrm{T}^{*}$ ) of $\mathrm{F}$ and LixF for DMI was 6-7 days longer than the age of PixF. This results show that PixF reach to maximum dry matter intake in 6-7 days earlier than $\mathrm{F}$ and LiXF while DMI at point of inflection $\left(\mathrm{W}^{*}\right)$ was higher for $\mathrm{F}$ (82.9 $\mathrm{kg}$ ) compared to LixF (79.8 kg) and PixF (80.7 kg). $\mathrm{U}_{6}$ and $\mathrm{U}_{16}$ and $\mathrm{K}^{*}$ were slightly higher in PixF. F reached to $75 \%$ of the mature dry matter intake later than crosses. 
ADMI until 6 months of age was statistically different between genotypes whereas the differences for ADMI from 6 to 16 months were insignificant. ADMI until 6 months of age was higher for PixF while it was similar for F and LixF.

A
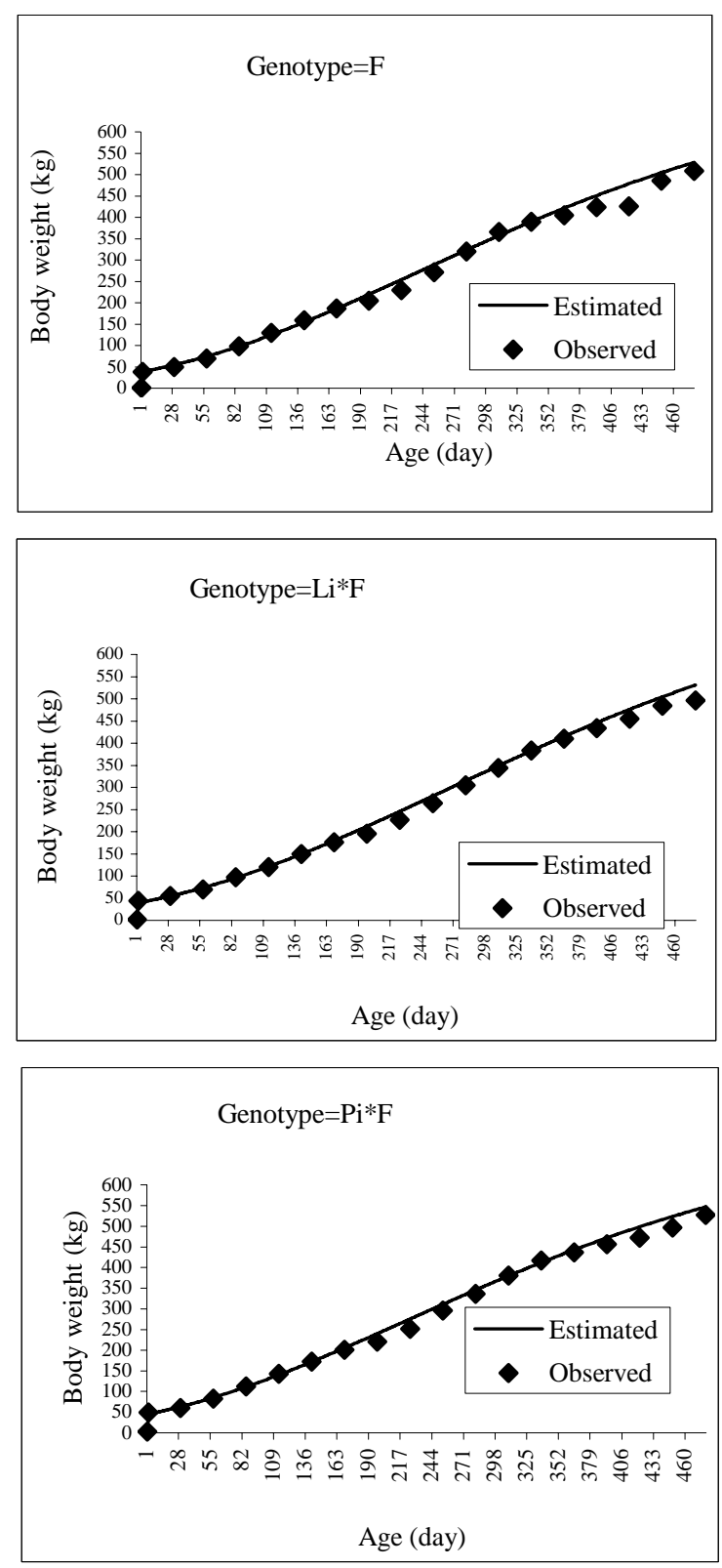

B
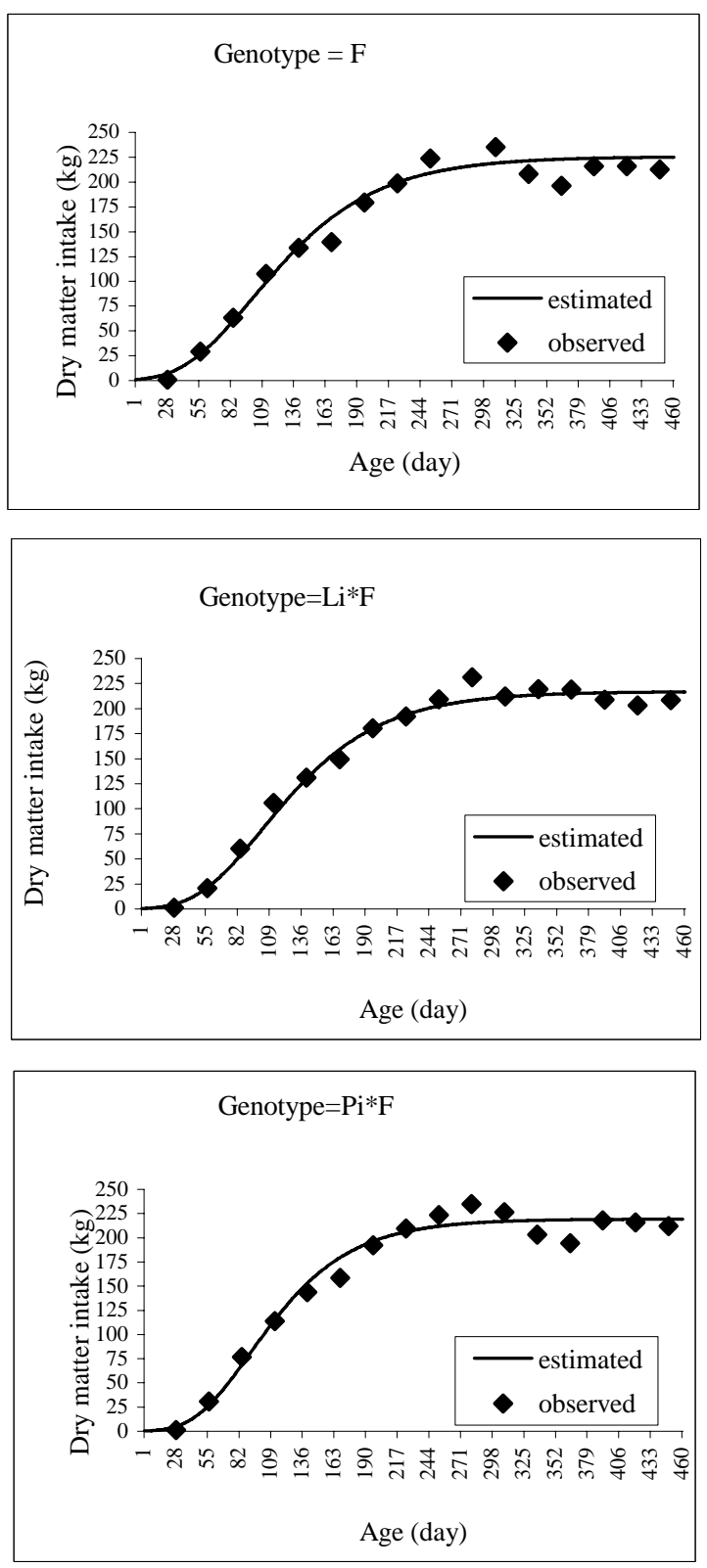

Fig. 1: Estimated and observed growth curves of F, LixF and PixF cattle for body weight (A) and dry matter intake(B) (Geschätzte und beobachtete Wachstumskurve von F, LixF und PixF für Körpergewicht und Trockenmasseaufnahme) 


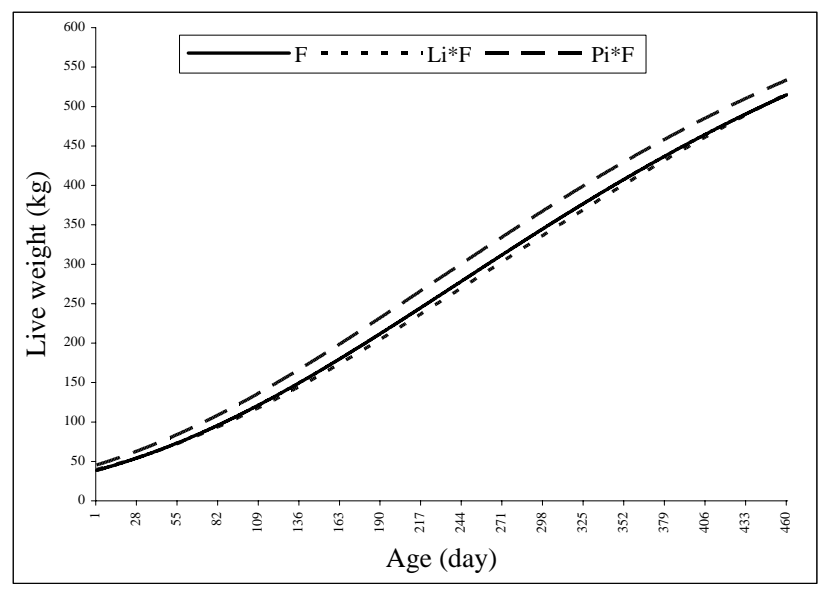

A

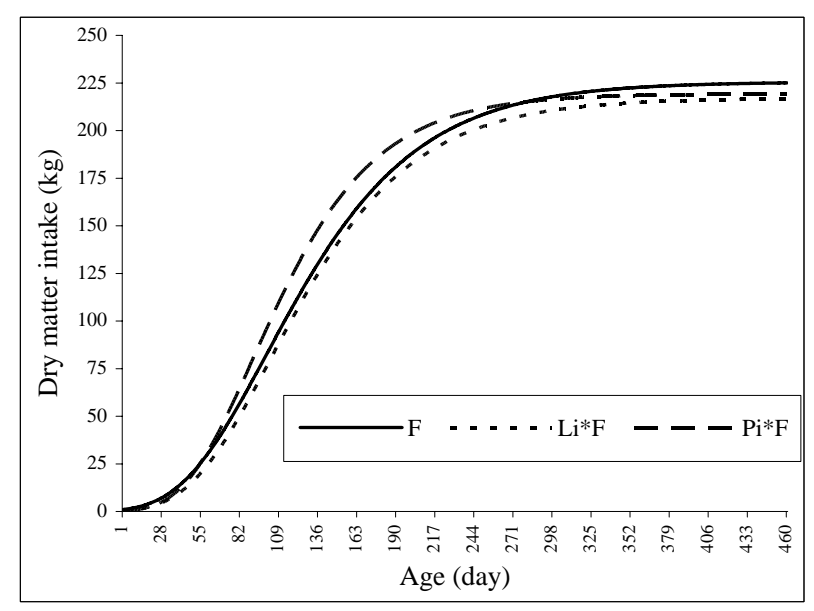

B

Fig. 2: Estimated growth curves of F, LixF and PixF cattle for body weight (A) and dry matter intake (B) (Geschätzte Wachstumskurve von F, LixF und PixF für Körpergewicht und Trockenmasseaufnahme)

\section{Correlations between curve parameters of BW and DMI}

Phenotypic correlation coefficients between the curve parameters for BW and DMI were given in Table 4. Correlation coefficients of $\mathrm{A}(\mathrm{BW})$ with $\mathrm{A}(\mathrm{DMI}), \mathrm{T}^{*}(\mathrm{DMI}), \mathrm{W}^{*}$ (DMI) were positive while it was negative between A (BW) and K (DMI). This reflected that animal, which matured later, tended to have higher DMI at mature. High DMI gain causes to light BW at mature. The more time reach maximum DMI, the higher BW at mature.

Since parameter $\mathrm{B}(\mathrm{BW})$ is negatively related to birth weight, negative correlation between $\mathrm{B}(\mathrm{BW})$ and $\mathrm{K}(\mathrm{DMI})$ reflects that heavier birth weights were associated with increasing rate in DMI. The positive correlation between $\mathrm{B}(\mathrm{BW})$ and $\mathrm{T}^{*}(\mathrm{DMI})$ or $\mathrm{W}^{*}$ (DMI) can be interpret that animals with low birth weights reach to their maximum DMI rate after a long period and more DMI at point of inflection.

Table 4

Correlation coefficients between growth curve parameters for body weight and dry matter intake (Korrelationskoeffizienten zwischen Wachstumskurvenparameter für Körpergewicht und Trockenmasseaufnahme)

\begin{tabular}{|c|c|c|c|c|c|c|c|c|c|c|c|}
\hline \multirow[b]{2}{*}{ Body weight } & \multicolumn{11}{|c|}{ Dry matter intake } \\
\hline & $\mathrm{A}$ & $\mathrm{B}$ & $\mathrm{K}$ & $\mathrm{T}^{*}$ & $\mathrm{~W}^{*}$ & $\mathrm{U}_{6}$ & $\mathrm{U}_{16}$ & $\mathrm{~T}_{0.75 \mathrm{~A}}$ & $\mathrm{~K}^{*}$ & $\mathrm{DMI}_{0-6}$ & $\mathrm{DMI}_{6-16}$ \\
\hline $\mathrm{A}$ & $.63^{* *}$ & -.37 & $-.54 * *$ & $.58 * *$ & $.63^{* *}$ & -.58 & $-.64 * *$ & $.63^{* *}$ & -.42 & -.29 & .48 \\
\hline B & $.55^{* *}$ & -.23 & $-.51^{*}$ & $.76^{* *}$ & $.55^{* *}$ & $-.72 * *$ & $-.73 * *$ & $.55^{* *}$ & -.42 & $-.62 * *$ & .28 \\
\hline K & $-.54^{*}$ & $.45^{*}$ & $.61^{* *}$ & $-.57 * *$ & $-.54 *$ & $.62 * *$ & $.65^{* *}$ & $-.54 *$ & $.54 *$ & .41 & -.35 \\
\hline $\mathrm{T}^{*}$ & $.56^{* *}$ & -.36 & $-.56^{* *}$ & $.63^{* *}$ & $.56^{* *}$ & $-.63^{* * *}$ & $-.68 * *$ & $.56^{* *}$ & $-.48^{*}$ & $-.44 *$ & .33 \\
\hline $\mathrm{W}^{*}$ & $.63^{* *}$ & -.37 & $-.54 *$ & $.58 * *$ & $.63^{* *}$ & $-.58 * *$ & $-.64 * *$ & $.63^{* *}$ & -.42 & -.29 & .48 \\
\hline $\mathrm{U}_{0}$ & $-.57 * *$ & .38 & $.59 * *$ & $-.66^{* *}$ & $-.57 * *$ & $.69 * *$ & $.69^{* *}$ & $-.57 * *$ & $.51^{*}$ & $.53^{*}$ & -.34 \\
\hline $\mathrm{U}_{6}$ & -.60 & .40 & $.62 * *$ & $-.68 * *$ & $-.60 * *$ & $.71^{* *}$ & $.73^{* *}$ & -.60 & $.53 *$ & $.51^{*}$ & -.38 \\
\hline $\mathrm{U}_{16}$ & -.57 & .37 & $.58^{* *}$ & $-.65^{* *}$ & $-.57 * *$ & $.65^{* *}$ & $.69^{* *}$ & $-.57 * *$ & $.49^{*}$ & $.46^{*}$ & -.35 \\
\hline $\mathrm{T}_{0.75 \mathrm{~A}}$ & $.54 *$ & -.38 & $-.56 * *$ & $.59 * *$ & $.54 * *$ & $-.60 * *$ & $-.65 * *$ & $.54 *$ & $.49 *$ & -.40 & .34 \\
\hline $\mathrm{K}^{*}$ & $.63^{* *}$ & -.14 & -.28 & $.44^{*}$ & $.63 * *$ & -.40 & $-.44 *$ & $.63^{* *}$ & -.06 & -.03 & $.64^{* *}$ \\
\hline $\mathrm{ABWG}_{0-6}$ & -.09 & .12 & .29 & -.40 & -.09 & .39 & .39 & -.09 & .35 & $.52 *$ & .17 \\
\hline $\mathrm{ABWG}_{6-16}$ & $.69 * *$ & -.40 & $-.53 *$ & $.48^{*}$ & $.69^{* *}$ & $-.55 *$ & $-.57 * *$ & $.69 * *$ & -.35 & -.16 & $.64^{* *}$ \\
\hline
\end{tabular}

The correlation coefficients between $\mathrm{K}$ (BW) and A (DMI) or $\mathrm{W}^{*}$ (DMI) show that growth rate was associated negatively with DMI at mature and DMI in age at point of inflection age. The animals which grew earlier tents to show lower mature DMI. Correlation coefficients between $\mathrm{K}(\mathrm{BW})$ and $\mathrm{K}(\mathrm{DMI})$ or $\mathrm{K}^{*}$ (DMI) were positive. 
The more animal grow fast, the higher DMI rate it has. Likewise the correlation coefficient between $\mathrm{K}(\mathrm{BW})$ and $\mathrm{T}^{*}(\mathrm{DMI})$ or $\mathrm{T}_{0.75 \mathrm{~A}}(\mathrm{DMI})$ were negative and reflects that animals which grew faster tents to reach earlier to the age at point of inflection and the age at $75 \%$ of mature DMI.

Correlation coefficients of age at point of the inflection for $\mathrm{A}(\mathrm{BW})$ with $\mathrm{A}(\mathrm{DMI})$, $\mathrm{T}^{*}(\mathrm{DMI}), \mathrm{T}_{0.75 \mathrm{~A}}(\mathrm{DMI}), \mathrm{W} *(\mathrm{DMI})$ were positive but it was negative between $\mathrm{T}(\mathrm{BW})$ and $\mathrm{K}(\mathrm{DMI})$ or $\mathrm{K} *(\mathrm{DMI})$. The animals with the longer accelerated phase had higher mature DMI but lower rate of DMI.

\section{Discussion}

The results obtained using data from young bulls in this study indicate that PixF animals grew slightly faster with shorter maturity intervals and reach slightly lighter mature weight than $\mathrm{F}$ and LixF, although differences were insignificant. On contrary, LixF exhibited higher mature weights, as it had slow maturity rates and longer maturity intervals compared to the other genotypes. This findings is convenient to other findings which is reported no significant differences in growth rate between Friesians and its crosses with Piemontese and Limousin (PILLA et al., 1987; SABBIONI et al., 1994). Inverse relationship between mature weight and maturity rate in cattle was also observed in the present study as observed in other numerous reports (BULLOCK et al., 1993; BELTRAN et al., 1992; PEROTTO et al., 1994). Besides, most of authors referred to negative and high correlation between rate of maturing and mature weight (MARSHALL et al., 1984; DENISE and BRINKS, 1985; MEYER, 1995; CARRIJO and DUARTE, 1999; KRATOCHVILOVÁ et al., 2002, JACUBEC et al., 2003).

Although there are several reports on growth curve parameters of cattle related to live weight of animal, there have been few reports on curve parameters related to feed intake. However, CHAMBAZ et al. (2001) and GOYACHE et al. (2003) suggest that considering only the $\mathrm{BW}$ of animal seems to be highly controversial to discuss improved biological efficiency. A genotype with high growth rate may not necessarily provide an improvement in biological efficiency over a slower growing animal with the same mature size. Despite having the same mature size, animal that have higher growth rate may have higher feed costs at maturity than the slower growing animal. THOMPSON and BARLOW (1986) showed that the changes in the shape of the growth curve can result from pattern of feed intake. It is easy to comment on growth of animal if feed intake was considered. The present results indicate that faster maturity for BW could lead to lighter DMI at inflection point and maturity as mentioned in correlation results. In this study, DMI curve is similar to pattern reported by HICKS et al. (1990) who reported that DMI of feedlot cattle increases rapidly during the earlier of a finishing period and then become consistent for a period, later declines when the animal is near its finished body weight. However DMI curve shape of F showed a tendency to increase and curve was upper than those of crosses. This may be explained with lower feed intake capacity of LixF and PixF because of their double muscle characterization. Likewise FIEMS et al. (1999) proposed that double-muscle animals are characterised by a reduced feed intake capacity. THOMPSON and BARLOW (1986) who studied the relationship between biological efficiency (lean tissue produced / food consumed) and stage of maturity of the progeny in cattle, reported that 
a stage of maturity at slaughter increases. In the present study, degree of maturity $\left(\mathrm{U}_{16}\right)$ was higher but the age of animal reached to $75 \%$ of the mature weight $\left(\mathrm{t}_{0.75 \mathrm{~A}}\right)$ was lower in PixF compared to F and LixF, although differences were found insignificant. Degree of maturity for DMI was also higher in PixF whereas the age of animal reached to $75 \%$ of the DMI $\left(\mathrm{t}_{0.75 \mathrm{~A}}\right)$ was lower in LixF compared to PixF.

Consequently, LixF genotype had slower maturity rates and therefore, their maturity intervals were longer than F and PixF. However, lower growth rate and long growing period resulted in high mature weight and lower DMI in LixF. PixF is earlier maturing genotype in a short period in this study and had lower DMI than F and very close DMI to LixF. At very early age (from birth to 6 months), it is possible to distinguish among $\mathrm{F}, \mathrm{LixF}$ and PixF according to their relative weight gains but it is not possible at 6-16 months of age. However, this findings showed that using of PixF as beef animal material might be met Turkish beef producer's demands of rapid maturing beef and feed cost might be decreased in beef cattle farm under intensive feeding system.

AKBAS, Y.:

\section{References}

Comparison of growth curve estimation models. Tr. J. Anim. Prod., 36 (1995), 73-81

ALCICEK, A.; ONENC, A.; GUNGOR, M.:

Carcass and meat quality of Friesian, Piemontese $\mathrm{x}$ Friesian and Limousin $\mathrm{x}$ Friesian young bulls under intensive beef production system in Turkey. J. Anim. Feed Sci. 12 (2003) 2, 249-260

ARCHER, J.A.; HERD, R.M.; ARTHUR, P.F.; PARNELL, P.F.:

Correlated responses in rate of maturation and mature size of cows and steers to divergent selection for yearling growth rate in Angus cattle. Livest. Prod. Sci., 54 (1998), 183-192

ARTHUR, P.F.; ARCHER, J.A.; HERD, R.M.; RICHARDSON, E.C.:

A review of variation in feed efficiency of beef cattle. Proceedings of the 6th World Congress on Genetics Applied to Livestock Production. Australia, Vol 25 (1998), 85-88

BELTRAN, J.J.; BUTTS JR., W.T.; Jr T. A.; OLSON, T.A.; KOGER, M.:

Growth patterns of two lines of Angus cattle selected using predicted growth parameters. J. Anim. Sci., 70 (1992), 734-471

BULLOCK, K.D.; BERTRAND, J.K.; BENYSHEK, L.L.:

Genetic and environmental parameters for mature weight and other growth measures in Polled Hereford cattle. J. Anim. Sci. 71 (1993), 1737-1741.

CARRIJO, S. M.; DUARTE, F.A.M.:

Description and comparison of growth parameters in Chianina and Nelore cattle breeds. Gen. and Molec. Biol., 22 (1999) 2, 187-196.

CHAMBAZ, A.; MOREL, I.; SCHEEDER, R.L.; KREUZER, M.; DUFFEY, P.A.:

Characteristics of steers of six beef breeds fattened from eight months of age and slaughtered at a target level of intramuscular fat. I. Growth performance and carcass quality. Arch. Tierz., Dummerstorf $\mathbf{4 4}$ (2001), 395-411

DENISE, S.K.; BRINKS, J.S.:

Genetic and environmental aspects of the growth curve parameters in beef cows. J. Anim. Sci., 61 (1985), 1431-1440

FIEMS, I.O.: VAN HOOF, J.; UYTTERHAEGEN, L.; BONEQUE, CH. V.; DEMEYER, D.I.: Comparative quality of meat from double-muscled and normal beef cattle. In: Quali, A. Denemeyer, D., Smulders, F.J.M. (Eds.), Expression of Tissue Proteinases and Regulation of Protein Degradation as Related to Meat Quality. Ecceamst. Utrecht (1999), 381-393

FREELICH, J.; VORISKOVA, J.; KUNIK, J.; KVAPILIK, J.: Mast- und Schlachtleistungen von Bullen aus Gebrauchskreuzungen tschechischer Rinderrassen mit Fleischrinderrassen. Arch.Tierz., Dummerstorf 41 (1998), 533-544

GOLZE, M.:

Wachstum, Schlachtleistung und Schlachtkörperqualität von Weidemastkälbern aus der Mutterkuhhaltung mit Fleischrindrassen. Arch. Tierz., Dummerstorf 44 (2001) 6, 621-627

GRUNDY, H. F.; HARDY, R.; CHAPPLE, D. G.; DAVIES, M. H.: 
Performance of late maturing beef $x$ dairy cattle finished on grass silage. Irish J. Agric. Food Res. 39 (2000) 3, 409-417

GOYACHE, F.; FERNANDEZ, I.; ROYO, L.; ALVAREZ, I.; GUTIERREZ, J.P.:

Factors affecting actual weaning weight, preweaning average daily gain and relative growth rate in Asturianna de los Valles beef cattle. Arch. Tierz., Dummerstorf 46 (2003), 235-243

GUNGOR, M.; ALCICEK, A.; ONENC, A.:

Feedlot performance and slaughter traits of Friesian, Piemontese $\mathrm{x}$ Friesian and Limousin $\mathrm{x}$ Friesian young bulls under intensive beef production system in Turkey. J. Appl. Anim. Ress. 24 (2003) 2, 129136

HICKS, R.B.; OWENS, F.N.; GILL, D.R.; OLTJEN, J.W.; LAKE, R.P.:

Daily dry matter intake by feedlot cattle: influence of breed and gender. J. Anim. Sci, 68 (1990), 245253

HOVING-BOLINK, A.H.; HANEKAMP, W.J.A.; WALSTRA, P.:

Effects of sire breed and husbandry system on carcass, meat and eating quality of Piemontese and Limousin crossbred bulls and heifers. Lives. Prod. Sci., 57 (1999), 273-278

HRÛSKA, K.:

The use of Piemontese bulls in commercial crossbreeding in dairy herd. Nás Chov., 53 (1993), 125-127

JACUBEC, V.; SCHLOTE, W.; RIHA, J.; MAJZLIK, I.:

Comparison of growth traits of eight beef cattle breeds in the Czech Republic. Arch. Tierz., Dummerstorf 46 (2003), 143-153

KRATOCHVILOVÁ, M.; HYÁNKOVÁ, L.; KNÍŽETOVÁ, H.; FIEDLER, J.; URBAN, F.:

Growth curve analysis in cattle from early maturity and mature body size viewpoints. Czech J. Anim. Sci., 47 (2002) 4, 125-132

LEHMANN, R.:

Theoretische Betrachtung zur Anwendung der Wachstumsfunktionen. Arch. Tierz., Berlin 22 (1979) 4, 381-393

MARSHALL, T.E.; MOHLER, M.A.; STEWART, T.S.:

Relationship of lifetime productivity with mature weight and maturation rate in Red Poll cows. Anim. Prod., 39 (1984), 383-387

MATTHES, H. D.; RUDOLPH, P.E.; HERRENDÖRFER, G.:

Verwendung von Wachstumsfunktionen zur Charakterisierung des Wachstums von Fleischrindrassen. Arch.Tierz., Dummerstorf 39 (1996), 121-127

MCGUIRK B, J.; GOING, I.; GILMOUR, A. R.:

The genetic evaluation of beef sires used for crossing with dairy cows in the UK. 1. Sire breed and nongenetic effects on calving survey traits. Anim. Sci., 66 (1998), 35-45

MEYER, K.:

Estimates of genetic parameters for mature weight of Australian beef cows and its relationship to early growth and skeletal measures. Livest. Prod. Sci., 44 (1995), 125-137

NAUMANN, C.; BASSLER, R.:

Methodenbuch, Band III., Die chemische Untersuchung von Futtermitteln. VDLUFA-Verlag, Frankurt (1993)

NELSEN, T.C.; LONG, C.R.; CARTWRIGHT, T.C.:

Postinfection growth in straightbred and crossbred cattle. II. Relationships among weight, height and pubertal characters. J. Anim. Sci., 55 (1982), 293-304

NEŠETŘILOVÁ, H.; ŠAŘECOVÁ, P.; LOUDA, F.; NOVÁ, V.:

Multiphasic growth models in cattle. Czech University of Agriculture, (1999), 145 pp

NRC:

Predicting feed intake of food producing animals. National Academy Press, Washington D.C., (1987)

PAPSTEIN, H.J.; KÜCHENMEISTER, U.; HARTUNG, M.; ENDER, K.; LOSAND, B.:

Untersuchungen zum Einfluss der Ernährungsintensitet auf den Wachtumsverlauf, Nährstoffansatz und Nährwert der Essbaren Gewebe von Bullen des Schwarzbunten Rindes. Arch. Tierz., Dummerstorf 38 (1995) 1, 33-41

PILLA, A.M.; CATILLO, G.; GIGLI, S.; ROMITA, A.:

Confronto fra vitelli meticci (Chianini, Charolaises, Limousines, Marchigiani, Piemontesi e Romagnoli) e puri su base materna Frisona.II-Efficienza biologica dell'accrescimento. Ann. Ist. Sper. Zootec., 20 (S.S.2) (1987), 27-44

PEROTTO, D.; CUE, R.I.; LEE, .J.; MCALLISTER, A.J.; BATRA, T.R.; LIN, C.Y.; ROY, G.L; WAUTHY, J.M.:

Additive and non-additive genetic effects of growth-curve parameters of Holstein, Ayrshire and crossbred females. Can J. Anim. Sci., 74 (1994), 401-409

SABBIONI, A.; SUPERCHI, P.; BONOMI, A.; MAZZALI, I.: 
Produzione del vitello a carne bianca con soggetti di razza Frisona Italiana (ITF) e con gli incroci Bianco Blu Belga x ITF, Piemontese x ITF e Garonnese x ITF. Rilievi in vita. Annali Fac. Med. Vet. di Parma, 14 (1994), 149-163

SPSS.:

Release 8 for windows SPSS Inc. Chicago, USA (1997)

THOMPSON, J.M.; BARLOW, R.:

The relationship between feeding and growth parameters and biological efficiency in cattle and sheep. Proceedings of the Third World Congress on Genetics Applied to Livestock Production. Nebraska, 11 (1986), 271-282

Received: 2005-08-15

Accepted: 2006-02-01

Author's addresses

Prof. Dr. YAVUZ AKBAS*, Prof. Dr. AHMET ALCICEK, Dr. ALPER ÖNENÇ

Ege University, Faculty of Agriculture, Department of Animal Science, Bornova, IZMIR, 35100, TURKEY

MEHMET GÜNGÖR

Ege Agricultural Research Institute, IZMIR, TURKEY

*Corresponding Author

E-Mail: yavuz.akbas@ege.edu.tr 